University of Wollongong

Research Online

Faculty of Engineering - Papers (Archive)

Faculty of Engineering and Information

Sciences

$1-1-2006$

\title{
Membrane fouling in the nanofiltration of landfill leachate and its impact on trace contaminant removal
}

Dirk Vogel

University of Wollongong

Bernd Bilitewski

Technische Universitat Dresden

Long Nghiem

University of Wollongong, longn@uow.edu.au

Follow this and additional works at: https://ro.uow.edu.au/engpapers

Part of the Engineering Commons

https://ro.uow.edu.au/engpapers/4239

\section{Recommended Citation}

Vogel, Dirk; Bilitewski, Bernd; and Nghiem, Long: Membrane fouling in the nanofiltration of landfill leachate and its impact on trace contaminant removal 2006, 295-303.

https://ro.uow.edu.au/engpapers/4239

Research Online is the open access institutional repository for the University of Wollongong. For further information contact the UOW Library: research-pubs@uow.edu.au 


\title{
MEMBRANE FOULING IN THE NANOFILTRATION OF LANDFILL LEACHATE AND ITS IMPACT ON TRACE CONTAMINANT REMOVAL
}

\author{
Dirk Vogel ${ }^{1.2}$, Bernd Bilitewskit, Long D Nghiem' \\ 'School of Civil, Mining \& Environmental Engineering \\ The University of Wollongong, Wollongong, NSW, 2522, Australia.

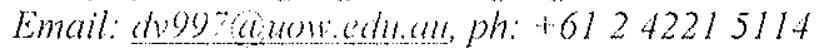 \\ IInstitute of Waste Management and Contaminated Site Treatment, Technische Universität \\ Dresden, Pralzschwizer Strasse 15, 01796 Pirna, Germany
}

\begin{abstract}
Landfilling is the most common municipal solid waste disposal method in Australia. During the decomposition of the deposited waste, leachate is generated mainly due to the seepage of stormwater through the landfill body. Landfill leachate is generally many times stronger than municipal sewage and therefore it must be collected and treated appropriately. Amongst the many treatment altematives available for landfll leachates, nanofiltration following a basic biological pre-treatment process is an attracting option as it can produce high effluent quality. However, membrane fouling is a major obstacle in the implementation of membrane filtration for leachate treatment. Fouling causes a flux decline, which reduces productivity of the membrane filtration process. In this study, labscale experiments using synthetic leachate were carried out under accelerated fouling conditions to study the foulng behaviour during the nanofiltration of landfill leachates. Leachate characteristics were summarised and delineated with respect to the fouling phenomena. Multivalent cations such as calcium in combination with organic matter, which is abundant in landfill leachate, were found responsible for the formation of a fouling layer on the membrane surface. It was also shown that the concentration of these multivalent cations could considerably influence the fouling process and subsequently the removal of bisphenol $A$ used as a model trace organic in this study.
\end{abstract}

\section{KEY WORDS}

Fouling, landfill leachate, membrane filtration, nanofiltration, trace organics, bisphenol $\mathrm{A}$.

\section{INTRODUCTION}

Waste generation and hence its management have been part of human existence on earth for thousands of years. Landfilling, i.e. disposal of the waste on or beneath the ground, for several reasons has been the most widespread method of waste management worldwide. Although alternative disposal technologies, such as incineration, are fully developed, cost and limited capacities of those altematives have led to an unbroken popularity of landfilling up to date. In Australia, landfilling is the most common method of waste disposal and solid waste from all streams i.e. municipal, commercial and industrial, construction and demolition, as well as controlled waste, are disposed off in landfills (Newton, 2001). In 1996/97, a total amount of 21.2 million tonnes of solid waste was sent to landfills, corresponding to a per capita disposal rate of more than 1.1 tonnes per annum. More than $95 \%$ of the total solid waste generated was received by landfills in some states and territories in 2001 (Newton, 2001). While there has been a considerable increase in recycling and waste diversion activities, this positive outcome has been offset by a steady increase in population.

Beside the emission of landfill gas, the release of leachate is the major route of interaction of a landfill with the environment and therefore is considered to pose the greatest potential for environmental harm (Christensen, 1989). Leachate is predominantly generated from precipitation onto the landfill surface, the moisture of the waste itself and to a limited extent potentially groundwater (if the bottom of the landfill is not lined) or other water infiltation (Bilitewski. 1997). During the percolation through the landfill body the water is severely contaminated with a complex mixture of organic and inorganic contaminants. Therefore collection and a following treatment is important for the protection of surface and subsurface watercourses and, depending on legislation, required in many countries (Anonymous, 1999).

According to Bilitewski ef al. all contaminated water that has been in contact with waste is defined as leachate (Bilitewski, 1997). Its formation is the result of complex hydrodynamic and physio-chemical processes within the landfill body. The expected quantity and cuality of the leachate depends on a number of parameters, e.g. climate, moisture conten of the waste disposed off, landfill operation, and landfill age. To set up a water balance for a (bottom lined) landfill precipitation and the moisture of the waste are considered the major inputs whereas evaporation, the collected leachate, and in some cases the surface run-off are outputs. Within the landfill water can be stored by the waste and due to biochemical processes water is mostly consumed since they mainly proceed under anaerobic conditions (Bilitewski, 1997; Melin, 2005). Guideline figures for leachate generation of 31 to $58 \%$ of the 
precipitation were reported for landfills with unconsolidated surface and 25 to $40 \%$ of the precipitation for landfills with compacted surface (Bilitewski, 1997).

Apart from the factors mentioned above, the characteristics of landfill leachate also depend on a number of other parameters such as waste composition, the biochemical decomposition of the waste within the landfill, its ply range, and the amount of water retained (Bilitewski, 1997). Thus, the leachate composition varies significantly among landfills. During the passage through the waste the water collects a wide range of organic and inorganic chemicals. Leachate from municipal landfills typically contains 0.2 to $1.5 \%$ solutes, of which the largest portion (80 to $95 \mathrm{w} \%$ ) consists of monovalent salts (Dahm, 1994). Furthermore, leachate may contain a large amount of inorganic nitrogen compounds, mainly as ammonia. A small portion (approx. up to $1 \mathrm{~g} / \mathrm{L}$ ) of the inorganic contents of leachate is made up by heavy metals. The remaining 5 to $20 \mathrm{wt} \%$ are made up of organic compounds. Christensen et al. (Christensen, 1989) classified leachate pollutants from a typical sanitary landfill receiving municipal and commercial wastes (no industrial waste) into four groups: (1) Common inorganic cations and anions; (2) Heavy metals; (3) Organic matter; and (4) Specific organic compounds (originating from household or industrial chemicals, present in relatively low concentrations, usually less than $100 \mathrm{ug} / \mathrm{L}$ ). In particular, the occurrence of these specific organic compounds of the last group at trace level has attracted many intensive research efforts over the last decade which revealed that an extensive range of organic compounds such as plasticisers (phthalates), pesticides, pharmaceuticals, polycyclic aromatic hydrocarbons, polychlorinated biphenyls, flame retardants can be found ubiquitously in landfill leachate (Yamamoto, 1999; Paxeus 2000; Behnisch, 2001). This, once again, underlines the necessity of sufficient treatment of the leachate 10 avoid negative environmental impact.

Most Australian landfills currently have an onsite pre-treatment process to reduce ammonia prior to sewer disposal as trade waste. However, as landfills are being located further away from metropolitan areas and sewage treatment plants, it would be a cost saving measure to have direct leachate disposal after being treated by advanced treatment processes, which can meet very stringent discharge regulations required. In fact, this has been proven to be an effective approach in Europe, particularly in Germany, Amongst several technologies currently available for the treatment of landfill leachate, nanofiltration (NF) has emerged as an attractive option since complementary combinations with pre-/post-treatment can be more cost effective than reverse osmosis applications that are most commonly used at present (Melin, 2005). Nanofiltration is, however, not suitable as a single process in landfill leachate treatment since it has a low rejection for nitrogen compounds (Trebouet, 2001) and can be subjected to severe fouling. Hence, combined processes are used in full-scale applications. These basically contain a biological treatment. However, it must be pointed out that for landfill leachate even a very comprehensive pre-treatment will not be able to completely eliminate potential fouling causing constituents. Thus, fouling will always be a part of membrane applications in the treatment of polluted water.

Membrane fouling can be defined as irreversible flux decline (and thus loss of perfomance), which can only be removed by, e.g. chemical cleaning. Fouling in NF: is a very important factor due to its negative impact on the competitiveness of the process. Generally fouling can be categorised in organic, inorganic, particulate, and biological fouling (Schäfer, 2005). Depending on the pre-treatment, organic and inorganic fouling probably exhibits the most significant impact on the application of NF for landfill leachate treatment. For landfill leachate, the fouling potential has been found to be high which is reflected by the fouling index ranging between 3.5 and 5.4 (Trebouet, 1999). Due to the high concentrations of organic matter in landfill leachate, organic fouling is expected to play a major role (Scott, 2005). Despite the high fouling propensity of leachate, the effects of membrane fouling on retention in the nanofilution process of landfil leachate have to date been largely overlooked. In fact, several studies investigating the nanofiltration of groundwater and secondary effuent have revealed some considerable effects of membrane fouling on the retention of organic contaminants ( $\mathrm{Xu}, 2006)$. These authors attributed the differences in the retention between virgin and (organically) fouled NJ membranes to the changed membrane characteristics. Nghiem et al. (Nghiem, 2002) reported a decrease in the trace organic estrone retention when the feed water contained natural organic matter compared to pure Milli-Q water. In other more recent studies, some observable effects of organic matter on the retention of several herbicides (Plakas, 2006) and on the membrane characteristics (Xu, 2006) have been reported. Furthermore, Plakas et al. suggested that the extent of membrane fouling as well as the structure of the foulants and solutes might have an influence on retention. Calcium was shown to affect retention of herbicides differently depending on whether it was applied alone or in conjunction with organic matter. While most of these findings to some degree demonstrate the importance of the feed water constituents in membrane filtration processes, the underlying mechanisms goveming membrane fouling and especially the influence of fouling on trace organic retention remain unclear.

In this sudy, the effects of natural organic matter in combination with calcium on the fouling behaviour of $N F$ membranes were investigated using a synthetic landfill leachate. Bisphenol $A$ (BPA), which is ubiquitous in landfill leachate and is also one of the most significan cndocrine disrupting chemicals, was selected as a model trace organic compound. Membrane filtration experiments were conducted under accelerated fouling conditions, thus, enabling a detailed examination of the fouling behaviour during landfill leachate nanofiltration processes. The influence of fouling on the retention of BPA and possible mechanisms were also delineated and discussed. 


\section{MATERIALS AND METHODS}

\section{Analytical Reagents and Chemicals}

All chemicals used in this investigation were of analytical grade and supplied by APS Australia, Auburn, NSW, Australia unless otherwise stated. Chemical solutions and feed waters were prepared with deionized (DI) water (Milli-Q Ultra Pure Water System, Millipore, North Ryde, NSW, Australia). Adjustments of the pH value were carried out using $1 \mathrm{M}$ sodium hydroxide $(\mathrm{NaOH})$ or $1 \mathrm{M}$ hydrochloric acid ( $\mathrm{HCl}$ ), respectively. A stock solution (1 g/L) of bisphenol A (Sigma Aldrich, Castle Hill, NSW, Australia) was prepared in pure methanol (HPLC grade). It was stored in the freezer at $-4^{\circ} \mathrm{C}$ and used within 1 month.

\section{Nanofiltration Membrane}

A commercially available NF membrane, namely NF-270 (FimTec Corp., Minneapolis, MN, USA), was used in this study. The membrane was received as flat sheet and was stored under dry conditions at room temperature. According to the manufacturer, the membrane is thin-film composite with a polyamide active layer on a microporous polysulfone supporting layer.

\section{Membrane Filtration Set-up \& Protocol}

A laboratory-scale crossflow NI: set-up (Figure 1) was used in this study. The NF/RO filtration unit comprises a stainless steel plate-and-frame membrane cell with an effective surface area of $7.7 \mathrm{~cm} \times 3.0 \mathrm{~cm}$, a $10 \mathrm{~L}$ stainless steel feed tank, and a Hydra-Cell pump (Wanner Engineering Inc., Minneapolis, MN, USA), Retentate flow rate was monitored by a rotameter. Feed pressure and crossflow velocity were controlled by means of a bypass valve and a back pressure regulator.

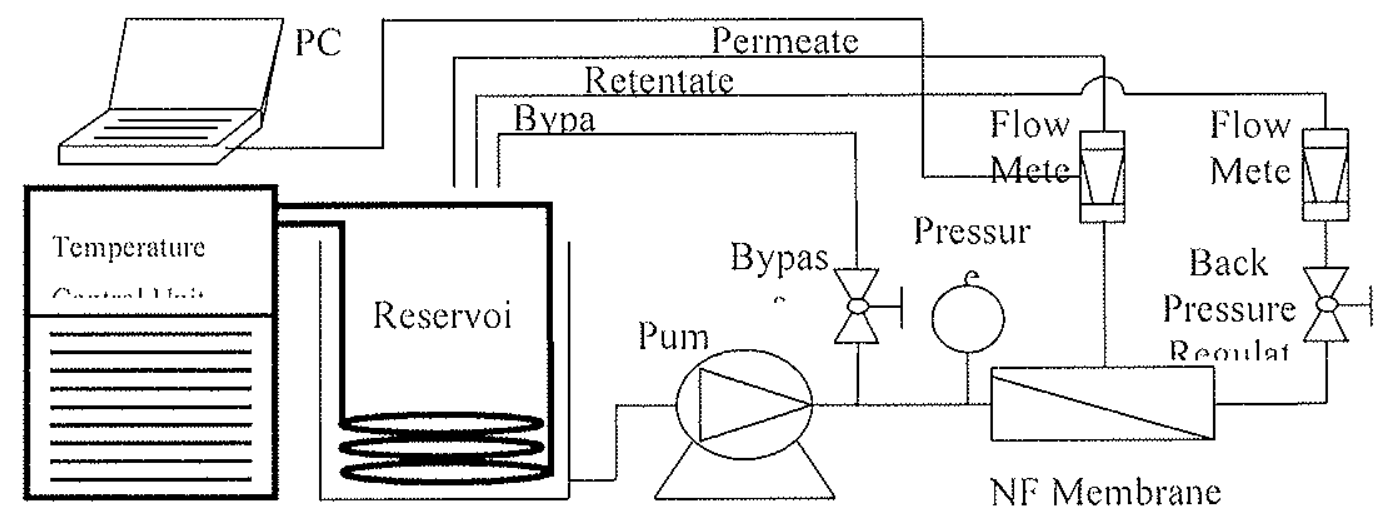

Figure 1: Schematic diagram of the laboratory-scale crossflow nanofiltration test unit.

Prior to every membrane filtration test two consecutive pre-treatment steps were carried out. Firstly, a membrane compaction was performed at a feed pressure of $130 \mathrm{kPa}$ for $1 \mathrm{~h}$ using DJ water in the feed tank. Then a fouling cocktail containing $1 \mathrm{mmol}$ of $\mathrm{NaHCO}_{3}, 20 \mathrm{mmol}$ of $\mathrm{NaCl}$ and $20 \mathrm{mg} / \mathrm{L}$. of humic acid (HA) was added to the feed tank and the fouling layer was established on the membrane surface by rumning the system at a pressure of $1000 \mathrm{kPa}$ for $18 \mathrm{~h}$. The total feed volume was $7 \mathrm{~L}$. Depending on the experiment, the concentration of $\mathrm{CaCl}_{2}$ was set to $0,0.5$, 1 or $4 \mathrm{mmol} / \mathrm{L}$ in the feed solution. Throughout the experiment, the permeate was recycled back to the feed tank after passing through a digital flow meter (Optiflow 1000, J\&W Humonics, Folsom, CA, USA) connected to a PC, to monitor the flow rate. All experiments were run at a cross-flow rate of $30.4 \mathrm{~cm} / \mathrm{s}$ and a constant temperature of the feed solution of $20( \pm 0.5)^{\circ} \mathrm{C}$, controlled by a circulating heater/chiller (Neslab RTE 7, Newington, NH, USA). A digital pH meter (Model 744, Metrohm, Herisatu, Switzerland) was used for the measurements of pH.

After the fouling development, the permeate flow rate was set to $3.7 \mathrm{~mL} / \mathrm{min}$ followed by the addition of BPA to make up a concentration of $750 \mu \mathrm{g} / \mathrm{L}$ in the feed solution. Samples of feed and permeate (approximately $1.5 \mathrm{~mL}$ ) were collected at specified intervals.

\section{Analytical Technique}

A Shimadzu high-performance liquid chromatography (HPLC, Rydalmere, NSW, Australia) system was used to analyse the organic contaminant bisphenol $\mathrm{A}$. The solvent delivery system included two HPLC pumps, a degaser, and a gradient mixer. A reversed phase column (Discovery ${ }^{\text {(3) }}$ C 8 with pore size, length, and diameter of $5 \mathrm{~mm}$, $250 \mathrm{~mm}$, and $5 \mathrm{~mm}$, respectively) supplied by Supelco (Castle Hil!, NSW, Australia) was used. The UV wavelength 
was set at $280 \mathrm{~mm}$. Premixed mobile phase was prepared using HPLC grade ACN and an aqueous buffer solution (DI water containing $25 \mathrm{mmol} / \mathrm{l}$ of $\left.\mathrm{KH}_{2} \mathrm{PO} \mathrm{O}_{\mathrm{f}}\right)$ : Eluent $\mathrm{A}(80 \% \mathrm{ACN} / 20 \%$ acjueous burfer solution) and eluent $\mathrm{B}$ $(20 \% \mathrm{ACN} / 80 \%$ aqueous buffer solution). Further details of this analysis is available elsewhere (Nghiem, 2005).

\section{RESULTS AND DISCUSSION}

\section{Landfill Leachate Characterisation}

A literature review was conducted to examine the typical compositions of the major constituents in landfill leachate. The results are summarised in Table 1, which clearly highlight the elevated salt concentrations and dissolved organic matter as the major constituents in landfill leachate. Furthermore, it is interesting to note that all parameters are subject to large variations, approximately 3 orders of magnitude or more. As a result of this literature review study, a model synthetic landfill leachate was selected to present the characteristics typical to those of real leachate (Table 1).

Table 1: Concentrations of salts and dissolved organic carbon in typical landfill leachate and composition of the synthetic leachate solution used in this study.

\begin{tabular}{|c|c|c|c|c|c|}
\hline \multirow[t]{3}{*}{ Parameter } & \multicolumn{3}{|c|}{ Real Landfill Leachate } & \multirow[t]{3}{*}{ References } & \multirow{3}{*}{$\begin{array}{c}\text { Synthetic Landfil } \\
\text { Leachate } \\
\mathrm{mg} / \mathrm{L}\end{array}$} \\
\hline & Concentration & $M$ & sart of DOC & & \\
\hline & $m g / l$ & $\%$ & $m g /$ & & \\
\hline \multirow[t]{3}{*}{ Sodium } & 2770 & & & $\left(X_{11}, 2006\right)$ & 483 \\
\hline & $0-8000$ & & & (Scolt. 2005) & \\
\hline & $200-1500$ & & & (Scolt, 2005) & \\
\hline \multirow[t]{2}{*}{ Calcium } & 38 & & & $(X u, 2006)$ & $0,20,40,160^{1}$ \\
\hline & $4-7200$ & & & $(\mathrm{Scot1}, 2005)$ & \\
\hline \multirow[t]{2}{*}{ Chloricle } & $34-11375$ & & & (Sco11. 2005) & 780 \\
\hline & $40-\{190$ & & & (Scolt, 2005) & \\
\hline \multirow[t]{4}{*}{ DOC } & 649 & 4 & 26 & $(X 11,2006)$ & $6^{2}$ \\
\hline & $\begin{array}{c}78-663 \\
\text { Avernge }(n=5)=388\end{array}$ & & & (Choi, 2006) & \\
\hline & $\begin{array}{c}57-138 \\
\text { Average }(n=3)=89\end{array}$ & & & (Namny, 2002) & \\
\hline & & $4-44$ & & $\begin{array}{c}\text { (Artiola } \\
\text { Fortumy: } \\
1982 \text { ), } \\
\text { (Castagnoli. } \\
1990 \text { ) } \\
\text { (Christensen, } \\
1998 \text { ) }\end{array}$ & \\
\hline
\end{tabular}

\footnotetext{
1 depending on the experiment

$20 \mathrm{mg} / \mathrm{l}$. HA added to feed water
}

\section{Physicochemical Properties of Bisphenol A}

Table 2: Physicochemical and toxicological characteristics of Bisphenol A (BPA)

$\begin{array}{lcl}\text { Formula } & \mathrm{C}_{15} \mathrm{H}_{16} \mathrm{O}_{2} \\ \mathrm{MW}(\mathrm{g} / \mathrm{mol}) & 228 \\ \mathrm{Solubilify} \text { in } \mathrm{Water}(\mathrm{mg} / \mathrm{L}) & 129 \\ \mathrm{pK}_{\mathrm{a}} & 10.1 \\ \mathrm{Log} \mathrm{K}_{\mathrm{ow}} & 3.32\end{array}$

Important physionchemical and toxicological properties of BPA are presented in Table 2 . BPA has a moderately high octanol-water partitioning coefficient ( $\log \mathrm{K}_{\mathrm{OW}}$ ) which indicates the hydrophobicity of the compound leading to an instant adsorption to hydrophobic materials. BPA is a weak acid with the two phenolic groups having a $p K_{\text {a }}$ value of 10.1. That means at the pH value present during the experiments (approximately 8.1 ) the functional groups are not dissociated so the compound remains neutral. 


\section{Influence of the Calcium Concentration on the Flux}

A clear impact of the feed water calcium concentration on the fux lyas been found in this study. Figure 2 shows the normalised flux profites over time during the fouling layer development phase (18 h) for 4 different calcium concentrations in the feed water. All curves show a relatively similar profile with an initial steep drop followed by a slowed down flux decline with time. The severeness of the flux decline over time depends on the calcium concentration as follows: $0.5 \mathrm{mM}>1 \mathrm{mM}>4 \mathrm{mM}>0 \mathrm{mM}$.

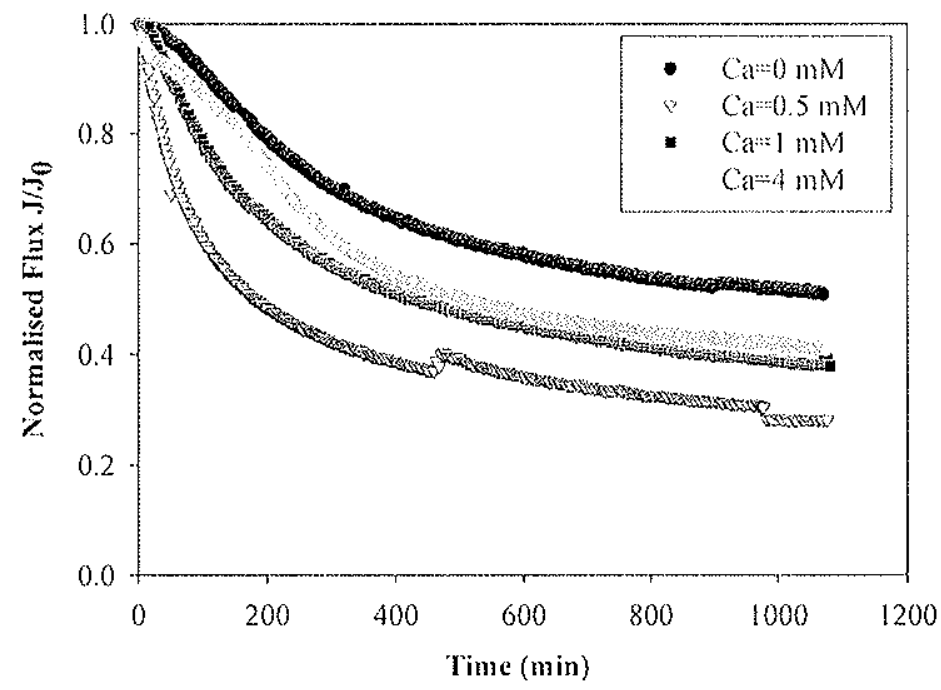

Figure 2: Influence of feed water calcium concentration on permeate flux for a NF-270 membrane. The feed water contained $750 \mu \mathrm{g} / \mathrm{L}, \mathrm{BPA}, 1 \mathrm{mM} \mathrm{NaHCO}, 20 \mathrm{mM} \mathrm{NaCl}, 20 \mathrm{mg} / \mathrm{L}$ humic acids and variable calcium concentrations, $\mathrm{pH}=8$.

Organic fouling is caused by the adsorption or deposition of organic matter to or on the membrane surface, gel formation, or pore blocking (Schäfer, 2005). All of these mechanisms may occur at the same time so it is not possible to determine the actual extent to which every single mechanism contributes to the fouling. As expected, the fux decline over time is lowest when no calcium is present. It drops to $52 \%$ of the initial value after $18 \mathrm{~h}$, which can be attributed solely to organic fouling due to the humic acid in the feed water (see Figure 3). Fouling increases as calcium is introduced to the feed water. However, it is interesting to note that fouling is more severe at 0.5 or 1 $\mathrm{mM}$ of calcium in the feed, while at $4 \mathrm{mM}$ fouling is less although it is still considerably higher than in the case where no calcium is involved. As can be seen in Figure 3 , the critical concentration of calcium in the feed water, at which fouling is most dramatic, appears to be approximately 0.5 or $1 \mathrm{mM}$.

The result reported here is consistent with several previous studies, which have demonstrated an increase in membrane fouling in the presence of calcium (and other multivalent cations) (Hong, 1997; Seidel, 2002; Teixeira, 2006). Intermolecular bridging between organic foulants and the membrane may be caused by cations(Seidel, 2002). Furthermore, positively charged calcium ions can form complexes with the functional groups of the humic acid (solute-solute interaction), resulting in a reduction of the interchain repulsion between the macromolecules of the humic acid and can lead to the formation of small and coiled macromolecules. In addition, the calcium ions partiy neutralise the negative charge of the membrane causing an increase in interaction between the membrane and the humic acid molecules. (Teixeira, 2006)

In this study a steep decrease of the curves for 0.5 and $1 \mathrm{mM}$ calcium was observed in the beginning of the run which is presumably caused by pore blocking by dense flocs. In contrast, the flux decreased more slowly in absence of calcium. At $4 \mathrm{mM}$ of calcium the run of the curve shows not such a steep drop in the beginning as at 0.5 and $1 \mathrm{mM}$, respectively. The flux decline over time slows down for all curves with the progress of the experiment and after approx, $500 \mathrm{~min}$ all curves run relatively parallel. It is assumed that this more gentle increase of fouling is attributed to a second fouling mechanism, namely the formation and compaction of the cake layer on the membrane surface after the pores have been blocked. The extent of fouling is most severe for $0.5 \mathrm{mM}$ of calcium which seems to be a critical concentration for fouling at the conditions given in this study. This is consistent with a previous study by Nghiem et al. who reported a peak in membrane fouling in the ultrafitration of greywater at a similar calcium concentration (Nghiem, 2006). It is hypothesised that a high calcium concentration may lead to the formation of large and compact aggregates (or flocs) that are bigger than the pores. Thus, they cannol penetrate into the membrane and cause pore blocking. In addition, the cake layer formed may be more porous which causes less hydraulic resistance and therefore the flux decline is less severe. In contrast, aggregates fomed are smatler at lower 
calcium concentrations which has been shown for colloidal systems (Nghiem, 2006). That results in a dense cake layer and/or pore blocking (Waite, 1999).

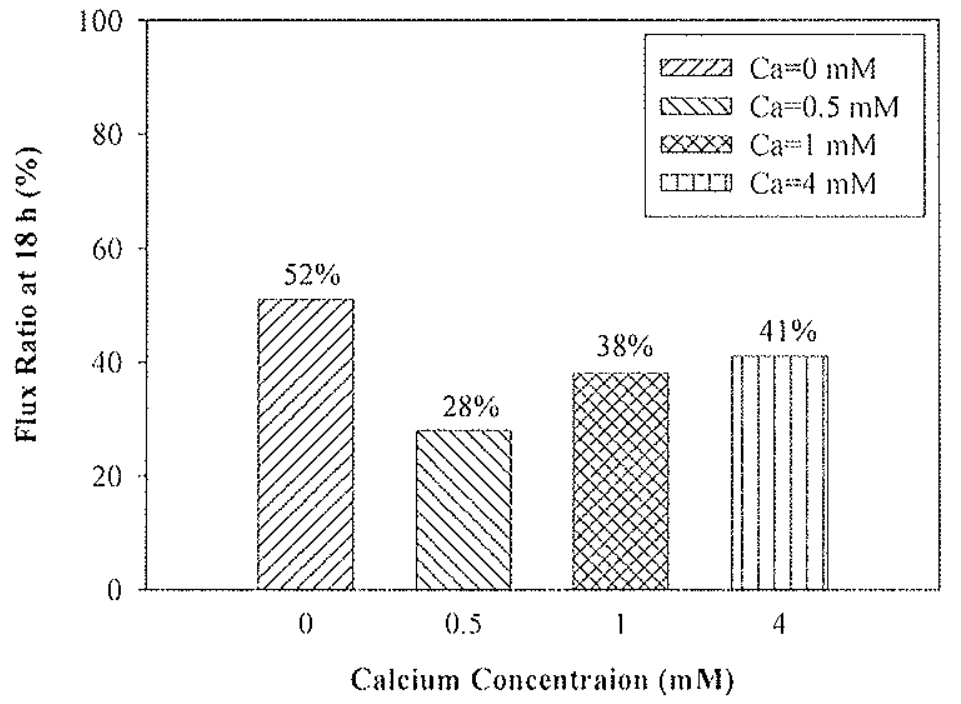

Figure 3: Permeate flux after $18 \mathrm{~h}$ of fouling layer development depending on calcium concentration in the feed water for a NF $-270 \mathrm{membrane}$. The feed water contained $750 \mu \mathrm{g} / \mathrm{L} \mathrm{BPA}, 1 \mathrm{mM} \mathrm{NaHCO}, 20 \mathrm{mM} \mathrm{NaCl}$, $20 \mathrm{mg} / \mathrm{L}$ humic acids and variable calcium concentrations, $\mathrm{pH}=8$.

\section{Influence of Fouling on the Retention of Organic Contaminants}

Similar to the fouling studies, membrane filtration tests with varying calcium concentrations were carried out. In Figure 4 the $B P A$ concentrations in feed water and permeate as well as the retention of BPA throughout the experiment are exemplary shown for a calcium concentration of $4 \mathrm{mM}$. The concentration of $B P A$ in the feed water slowly decreases in the course of the run from approximately $750 \mu \mathrm{g} / \mathrm{L}$ to $700 \mu \mathrm{g} / \mathrm{L}$. The permeate concentration increases sharply in the beginning of the test starting at approximately $75 \mu \mathrm{g} / \mathrm{L}$. The curve starts 10 stabilise from ca. $70 \mathrm{~min}$ and reaches $490 \mu \mathrm{g} / \mathrm{L}$ at $120 \mathrm{~min}$. After that only a very slight increase of the permeate BPA concentration was observed. Accordingly, the retention shows a sharp decrease in the beginning of the test, starting at $90 \%$ and reaching an almost stable level of approximately $30 \%$ after 10 hours.

An initial drop of the retention of BPA was observed for all calcium concentrations (data shown for $4 \mathrm{mM}$ of calcium only), however the extent was different which eventually lead to quite signiffcant differences in retention of BPA as shown in Figure 5. Adsorption of BPA to the membrane surface and possibly the bumic acid is responsible for the high retention in the beginning of the test which is consistent with previous studies where a significant adsorption of hydrophobic, neutral compounds onto NF membranes was found (Kimura, 2003). Nghiem et al. observed a similar initial drop of BPA retention stabilising at approx. $45 \%$ retention when rumning a feed water solution containing $10 \mathrm{mM}$ of NOM through a NJ 270 membrane (Nghiem, 2005). The low BPA retention for both 0 and $4 \mathrm{mM}$ of calcium correlates with less fouling compared to 0.5 and $1 \mathrm{mM}$ as described above. This effect may be attributed to limited pore blocking occurring when no calcium is present resulting in a less dense fouling layer. Al a concentration of $4 \mathrm{mM}$ of calcium large compact aggregates are formed that are too large to block pores and also form a fairly porous cake layer on the membrane surface. An additional effect, the prevention of back diffusion of solute into the bulk solution, has been described before $(\mathrm{Ng}, 2004)$. Following a higher concentration of the solute near the membrane the gradient lowards the permeate side increases which eventually leads to a diffusion of the solute through the membrane. For 0.5 and $1 \mathrm{mM}$ of calcium, respectively, small, coiled macromolecules are fomed that can cause pore blocking (Seidel, 2002). Besides an increase in fouling a simultaneous increase in retention of BPA was observed. Furthermore, the dense cake layer formed may increase the sieving effect so organic solutes are rejected. The counteracting process expected to affect the retention is the abovementioned hindered back diffusion which aids the diffusion of the solute though the membrane. Both mechanisms are thought to occur at the same time cannol be easily separated. 


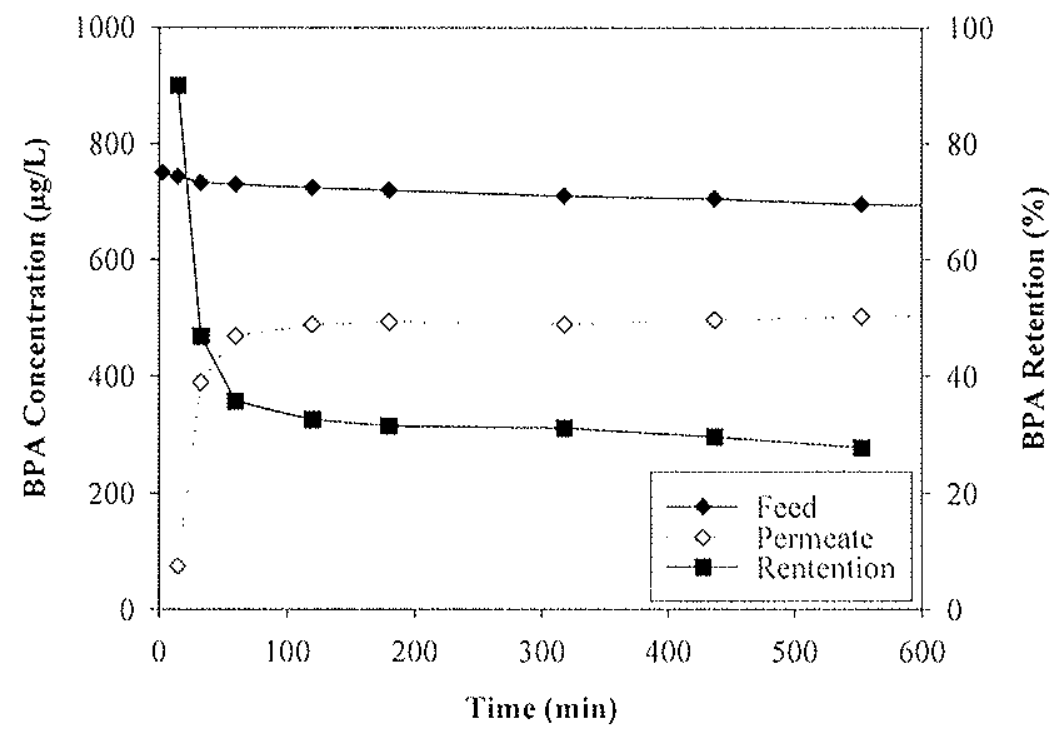

Figure 4: Concentrations of BPA in feed water and permeate and retention of BPA for a calcium concentration of $4 \mathrm{mM}$ in the feed water for a $\mathrm{NI}-270$ membrane. The feed water contained $750 \mu \mathrm{g} / \mathrm{L} \mathrm{BPA}, 1$ $\mathrm{mM} \mathrm{NaHCO}, 20 \mathrm{mM} \mathrm{NaCl}, 20 \mathrm{mg} / \mathrm{L}$ humic acids, $\mathrm{pH}=8$.

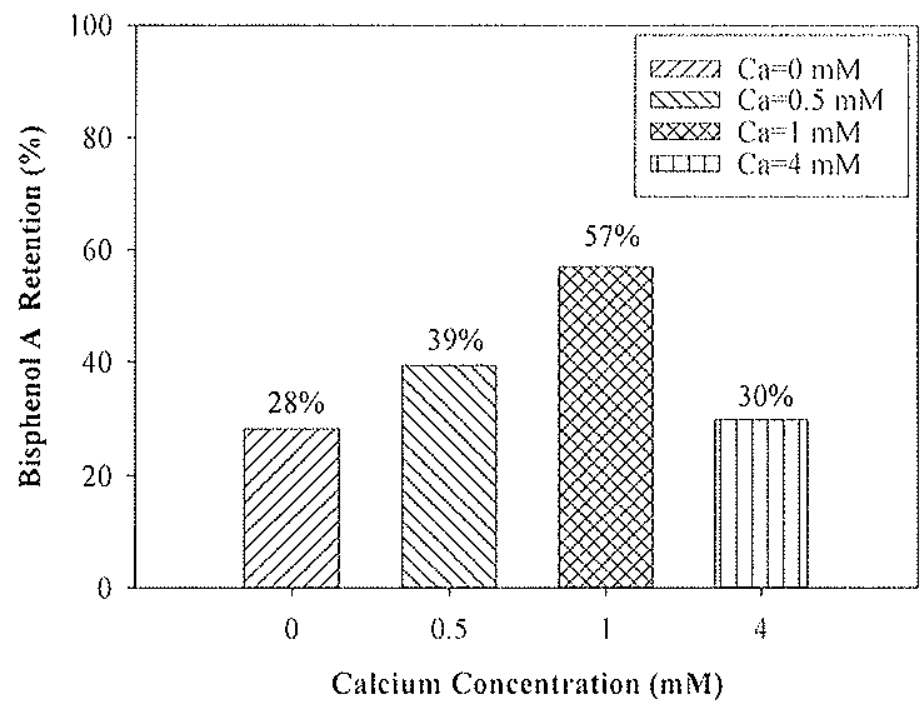

Figure 5: Retention of BPA by NF-270 membrane after $420 \mathrm{~min}$ ( $7 \mathrm{~h}$ ) of membrane retention test for a NF270 membrane. The feed water contained $750 \mu \mathrm{g} / \mathrm{L}, \mathrm{BPA}, 1 \mathrm{mM} \mathrm{NaHCO}, 20 \mathrm{mM} \mathrm{NaCl}, 20 \mathrm{mg} / \mathrm{L}$ humic acids and variable calcium concentrations, $\mathrm{PH}=8$.

\section{CONCLUSIONS}

The results reported here demonstrate a considerable effect of the feed water calcium concentration on membrane fouling. Fouling was most severe at $0.5 \mathrm{mM}$ whereas at no calcium or at a higher concentration (e.g. $4 \mathrm{mM}$ ) membrane fouling was considerably lower. Two major fouling mechanisms, pore blocking and cake layer formation, are assumed to take place. Both are caused by solute solute interactions (bridging and complexation) and solute-membrane interactions (bridging and charge neutralisation). The study also shows a significant influence of fouling on the retention of BPA. Low rejection coincides with low fouling at $0 \mathrm{mM}$ and $4 \mathrm{mM}$ of calcium, respectively. Retention increases with the extent of fouling although the highest retention (at $1 \mathrm{mM}$ of calcium) was not observed when fouling was most severe (at $0.5 \mathrm{mM}$ of calcium). Pore blocking and an enhanced sieving effect due to the cake layer increase the retention of BPA. On the other hand, the cake layer hinders back diffusion into the bulk solution which eventually promotes diffusion of BPA through the membrane.

\section{ACKNOWLEDGEMENTS}

The authors would like to acknowledge Deutscher Akademischer Austauschdienst (DAAD, Bonn, Germany) for providing a scholarship for doctoral studies for Dirk Vogel. Norm Gal and Joanne George are thanked for their extensive laboratory support. 


\section{REFERENCES}

1. Anonymous (1999). Conncil Directive 1999/31/EC of 26th April 1999 on the landfill of waste, European Community,

2. Artiola-Fortuny J, and W. H. Fuller (1982). "Humic substances in landfill leachate. 1. Humic acid extraction and identification." Joumal of Environmental Quality 11: 663-668.

3. Behnisch P. A., K. Fujii, K. Shiozaki, I. Kawakami and S. Sakai (2001). "Estrogenic and dioxin-like potency in each step of a controlled landfill leachate treatment plant in Japan." Chemosphere 43(4-7): 977-984.

4. Bilitewski B., G. Härdtle, K. Marek and a. H. B. translated and edited by A. Weissbach (1997). Waste Management. New York, Springer.

5. Castagnoli O, L. Musmeci, E. Zavattiero and M. Chirico (1990). "Humic Substances and Humification Rate in a Municipal Refuse Disposed of in a Landfill." Water Air and Soil Pollution 53(1-2): 1-12.

6. Choi K. I. and D. H. Lee (2006). "PCDD/DF in leachates from Korean MSW landfills." Chemosphere 63(8): $1353-1360$.

7. Christensen J. B., D. L. Jensen, C. Gron, Z. Filip and T. H. Christensen (1998). "Characterization of the dissolved organic carbon in landfill leachate-polluted groundwater." Water Research 32(1): 125-135.

8. Christensen T. H., P. Kjeldsen, J. Lyngkilde and J. C. Tjell (1989). Behaviour of leachate polfutants in groundwater. Sanitary Landfilling: Process, Technology and Envirommental Impac1, 9. T. H. Christensen, R. Cossu and R. Stegmann. London, Academic Press: 465.

9. Dahm W., J. S. Kollbach and J. Gebel (1994). Sickerwasserreinigung, Stand der Technik 1993/94. Berlin, EFVerlag für Energie und Unweltteclmik.

10. Hong S. and M. Elimelech (1997). "Chemical and physical aspects of natural organic matter (NOM) fouling of nanofiltration membranes." Journal of Membrane Science 132(2): 159-181.

11. Kimura K., G. Amy, J. Drewes and Y. Watanabe (2003). "Adsorption of hydrophobic compounds onto NF/RO membranes: an artifact leading to overestimation of rejection." Journal of Membrane Science 221(1-2): 89-101.

12. Melin T., J. Meier and T. Wintgens (2005). Nanofiltration in landfill leachate treatment. Nanofiltration Principles and Applications. A. I. Schäfer, A. G. Pane and T. D. Waite. Oxford, Elsevier: $396-413$.

13. Namny M. A. and N. Ratasuk (2002), "Characterization and comparison of hydrophobic neutral and hydrophobic acid dissolved organic carbon isolated from three municipal landfill leachates." Water Research 36(6): 1572-1584.

14. Newton P. W., S. Baum, K. Bhatia, S. K. Brown, A. S. Cameron, B. Forean, T. Grant, S. L. Mak, P. C. Memmott, V. G. Mitchel, K. L. Neate, A. Pears, M. Smith, R. J. Stimson, S. N. Tucker and D. Yencken (200I). 'Human Settlements'. Australia State of the Environment Report 2001 (Theme Report), CSIRO) Publishing, Canberra.

15. $\mathrm{Ng} \mathrm{H}$. Y. and $\mathrm{M}$. Elimelech (2004). "Influence of colloidal fouling on rejection of trace organic contaminants by reverse osmosis." Joumal of Membrane Science 244(1-2): 215-226.

16. Nghiem L. D., N. Oschmann and A. 1. Schafer (2006). "Fouling in greywater recycling by direct ultrafiltration." Desalination 187(1-3): 283-290.

17. Nghiem 1. D., A. 1. Schafer and T. D. Waite (2002). "Adsorption of estrone on nanofiltration and reverse osmosis membranes in water and wastewater treatment." Water Science and Technology 46(4-5): 265-272.

18. Nghiem L. D., A. 1. Schaffer and M. Elimelech (2005). "Nanofiltration of homone mimicking trace organic contaminants." Separation Science and Technology 40(13): 2633-2649.

19. Paxeus N. (2000). "Organic compounds in municipal landfill leachates." Water Science and Technology $42(7-$ 8): $323-333$.

20. Plakas K. V., A. J. Karabelasa, T. Wintgens and T. Melin (2006). "A study of selected herbicides retention by nanofiltration membranes - the role of organic fouling." Journal of Membrane Science 284( ]-2): 29] -300.

21. Schäfer A. I., N. Andritsos, A. J. Karabelas, E. M. V. Hoek, R. Schneider and M. Nyström (2005). Fouling in Nanofilatration. Nanofiltration - Principles and Applications. A. I. Schäfer, A. G. Fane and T. D. Waite. Oxford, Elsevier: $169-240$.

22. Scott J., D. Beydoun, R. Amal, G. Low and J. Cattle (2005). "Landfill management, leachate generation, and feach testing of solid wastes in Australia and overseas." Critical Reviews in Environmental Science and Technology $35(3): 239-332$.

23. Seidel A. and M. Elimelech (2002). "Coupling between chemical and physical interactions in natural organic matter (NOM) fouling of nanofiltration membranes: implications for fouling control." Journal of Membrane Science $203(1-2): 245-255$

24. Teixeira M. R. and M. J. Rosa (2006). "The impact of the water background inorganic matrix on the natural organic matter removal by nanofiltration." Joumal of Membrane Science 279(1-2): 513-520.

25. Trebonet D., J. P. Schlumpf, P. Jaouen, J. P. Maleriat and F. Quemeneu (1999), "Effect of operating conditions on the nanofiltration of landfill leachates: Pilot-scale studies." Environmental Technology 20(6): 587-596.

26. Trebouet D., J. P. Schlumpf, P. Jaouen and F. Quemeneur (2001). "Stabilized landfill leachate treatment by combined physicochemical-nanofiltration processes." Water Research 35(12): 2935-2942.

27. Waite T. D., A. I. Schafer, A. G. Fane and A. Hewer (1999). "Colloidal Fouling of Ultafiltation Membranes: Impact of Aggregate Structure and Size." Joumal of Colloid and Interface Science 212(2): 264-274. 
28. Xu P., J. E. Drewes, T.-U. Kim, C. Bellona and G. Amy (2006). "Effect of membrane fouling on transport of organic contaminants in NF/RO membrane applications." Journal of Membrane Science 279(1-2): 165-175.

29. Xu Y.-D., D..B. Yue, Y. Zhu and Y..F. Nie (2006). "Fractionation of dissolved organic matter in mature landfill leachate and its recycling by uitrafiltration and evaporation combined processes." Chemosphere 64(6): $903-911$.

30. Yamamoto T. and A. Yasuhara (1999). "Quantities of bisphenol A leached from plastic waste samples." Chemosphere 38(11): 2569-2576. 